$\begin{array}{ccc}\text { Tersedia online di: http://ejournal-balitbang.kkp.go.id/index.php/jppi } & \begin{array}{l}\text { JURNAL } \\ \text { PENELITIAN } \\ \text { PERIKANAN } \\ \text { INDONESIA }\end{array} \\ \text { JURNAL PENELITIANPERI.puslitbangkan@ @gmail.com } & \text { Volume 24 Nomor 4 Desember 2018 } \\ \text { p-ISSN: 0853-5884 } \\ \text { e-ISSN: 2502-6542 }\end{array}$

\title{
AKTIVITAS PENANGKAPAN DAN PRODUKSI IKAN DI KABUPATEN HULU SUNGAI UTARA KALIMANTAN SELATAN
}

\section{THE FISHING ACTIVITY AND FISH PRODUCTION IN HULU SUNGAI UTARA REGENCY SOUTH KALIMANTAN}

\author{
Aroef Hukmanan Rais ${ }^{\star 1}$, Tuah Nanda Merlia Wulandari ${ }^{1}$, dan Emmy Dharyati ${ }^{1}$ \\ 'Balai Riset Perikanan Perairan Umum dan Penyuluhan Perikanan, Jln. Gub. HA Bastari, No 8 Jakabaring, \\ Palembang, Sumatera Selatan, Indonesia \\ Teregistrasi I tanggal: 25 September 2018; Diterima setelah perbaikan tanggal: 16 Januari 2019; \\ Disetujui terbit tanggal: 29 Januari 2019
}

\begin{abstract}
ABSTRAK
Kabupaten Hulu Sungai Utara (HSU) memiliki potensi dengan total wilayah perairan umum mencapai $65 \%$ dari keseluruhan wilayahnya. Rawa banjiran menjadi sumber daya yang paling besar menopang perekonomian salah satunya dari hasil tangkapan perikanan tangkapnya. Tulisan ini menjelaskan kegiatan penangkapan dan hasil tangkapan ikan dalam hubungannya dengan fluktuasi tinggi permukaan perairan di Kabupaten Hulu Sungai Utara. Penelitian telah dilaksanakan pada Maret hingga Desember 2016, dengan melibatkan 16 orang nelayan pencatat hasil tangkapan. Nelayan berasal dari Palbatu dan Desa Tampakang, Kecamatan Danau Panggang. Data hasil tangkapan diperoleh dari 11 jenis alat penangkapan ikan yang terbagi dalam empat kelompok yaitu kelompok pancing/hook and line(pancing pelampung dan rawai baung), kelompok jebakan Ipot trap (lukah baung, jabak baung, tampirai dan tamba seluang), kelompok jebakan/barrier trap (hampang padang, selambau kasa, dan selambau sungai), dan kelompok jaring/gill net (lalangit dan rengge). Data tinggi permuka air secara rutin dikumpulkan oleh nelayan setempat. Nilai laju tangkap dan hasil tangkapan dikorelasikan dengan tinggi muka air melalui uji-t. Hasil penelitian menunjukkan alat penangkapan ikan lukah baung dan tampirai dapat digunakan sepanjang tahun. Alat penangkapan ikan selambau sungai memiliki nilai laju tangkapyang tertinggi. Nilai laju tangkap berkorelasi signifikat terhadap tinggi muka air, sedangkan nilai hasil tangkapan hasil tangkapan tidak berkorelasi signifikan terhadap tinggi permukaan air.
\end{abstract}

Kata Kunci: Alat penangkapan ikan; hulu sungai utara; hasil tangkapan ikan; rawa banjiran; tinggi permukaan air

\begin{abstract}
Hulu Sungai Utara Regency (HSU) has potency with total inland waters area about $65 \%$ from total administration area. The flood plain becomes the largest resources to sustain the economic through the fish catch production. This paper describes the fishing activity and fish production on relationship with water level fluctuation in Hulu Sungai Utara Regency. This research was conducted on March to December 2016, with involved 16 fishers whose collected the fishing data activity. They are come from Palbatu village and Tampakang village, Danau Panggang District. Catch data collected by 11 fishing gears which separated to four groups they are hook and line (pancing pelampung and rawai), pot trap (lukah baung, jabak baung,tampirai and tamba seluang), barrier trap (hampang padang, selambau kasa, and selambau sungai), and gill net (lalangit and rengge. The water level fluctuation data was collected by local fishermen. The catch rate and production were correlated by t-test analysis. The results show that lukah baung and tampirai might be used throughout the season. The Selambau sungai got the highest of the catching rate. The catching rateswere significant correlated to water level fluctuation. While, the fishing production was not significant correlated to water level fluctuation.
\end{abstract}

Keywords: Fishing gear; hulu sungai utara; fish production; flood plain; water level 


\section{PENDAHULUAN}

Kabupaten Hulu Sungai Utara (HSU), Kalimantan Selatan merupakan salah satu kabupaten yang memiliki potensi perikanan perairan umum yang besar. Menurut data BPS tahun 2015, hasil tangkapan perikanan Kabupaten Hulu Sungai Utara mencapai 12.258,7 ton (BPS HSU, 2014).Kabupaten Hulu Sungai Utara termasuk kedalam Daerah Aliran Sungai Barito bagian tengah. Kabupaten ini memiliki total wilayah perairan umum daratan mencapai sekitar $65 \%$ $(56.452 \mathrm{Ha})$ dari total wilayah administratifnya, sedangkan total wilayah rawa di Kabupaten ini mencapai $95 \%(54.129 \mathrm{Ha})$ dari total wilayah perairan umum (Dinas Perikanan HSU, 2015). Kegiatan perikanan tangkap menjadi salah satu potensi dan unggulan bagi masyarakat daerah. Hal ini juga yang menjadikan Kabupaten Hulu Sungai Utara memiliki Visi pengembangan lahan rawa untuk kesejahteraan masyarakat.

Perairan umum juga sangat erat hubungannya dengan pembangunan masyarakat miskin dan menengah, pembentukan kehidupan sosial, kualitas kesehatan, pendidikan dan juga struktur bermasyarakat bagi penduduk local (Béné, 2009). Kegiatan perikanan tangkap di wilayah rawa banjiran identik dengan perikanan skala kecil, alat penangkapan ikan yang bervariasi, dan sangat dipengaruhi oleh fluktuasi kondisi lingkungan perairan (Rupawan \& Aroef, 2016). Salah satu parameter kunci yang sangat mempengaruhi hasil tangkapan dan sumber daya perikanan di perairan umum adalah fluktuasi tinggi permukaan air, dimana parameter ini sangat berpengaruh dengan migrasi, biologi ikan, produktivitas, komposisi dan juga aktivitas tangkap itu sendiri (Kolding \& Zwieten, 2014). Fluktuasi tinggi permukaan air itu sendiri sangat dipengaruhi oleh banyaknya air masukan, runoff, Presitipasi, dan juga jumlah air tanah (Zohary \& Ostrovsky, 2011).

Penelitian ini bertujuan untuk menjelaskan pola aktivitas penangkapan ikan oleh masyarakat dalam hubungannya dengan fluktuasi tinggi permukaan perairan, hasil tangkapan dan komposisi hasil tangkapan pada berbagai jenis alat penangkapan ikan di perairan rawa banjiran Kabupaten Hulu Sungai Utara, Kalimantan Selatan.

\section{BAHAN DAN METODE Pengumpulan Data}

Pengambilan sampel lapangan dilakukan di lokasi penangkapan ikan DAS Barito, yaitu pada wilayah perairan rawa banjiran Kecamatan Danau Panggang, Kabupaten Hulu Sungai Utara, Provinsi Kalimantan Selatan pada 2016. Data pegamatan kegiatan penangkapan dikumpulkan selama sepuluh bulan yaitu dari Maret hingga Desember 2016. Adapun lokasi pengambilan sampel terdapat di Desa Palbatu dan Desa Tampakang, Kecamatan Danau Panggang, Kabupaten Hulu Sungai Utara, Kalimantan Selatan (Gambar 1). Pengambilan data alat penangkapan ikan dan hasil tangkapannya diperoleh dari 16 orang nelayan yang tersebar di dua desa tersebut. Terdapat 11 jenis alat penangkapan ikan yang terbagi dalam empat kelompok selama penelitian ini yaitu kelompok pancing / hook and line (pancing pelampung dan rawai baung), kelompok jebakan / pot trap (lukah baung, jabak baung, tampirai dan tamba seluang), kelompok jebakan / barrier trap (hampang padang, selambau kasa, dan selambau sungai), dan kelompok jaring / gill net (lalangit dan rengge) (Tabel1). Data yang dikumpulkan yaitu berupa data jenis ikan yang tertangkap dari berbagai alat penangkapan ikan, total bobot ikan yang tertangkap dan banyaknnya hari penangkapan. Data hasil tangkapan ditampilkan dalam nilai laju tangkap per bulan pengamatan. Data fluktuasi tingi permukaan air secara harian juga dikumpulkan peneliti dengan mengunakan papan tinggi muka air yang melibatkan seorang nelayan setempat. Ikan hasil tangkapan diidentifikasi dengan menggunakan buku Kottelat (1993) dan Froese \& Pauly (2016) dalam www.fishbase.org version (06/ 2016).

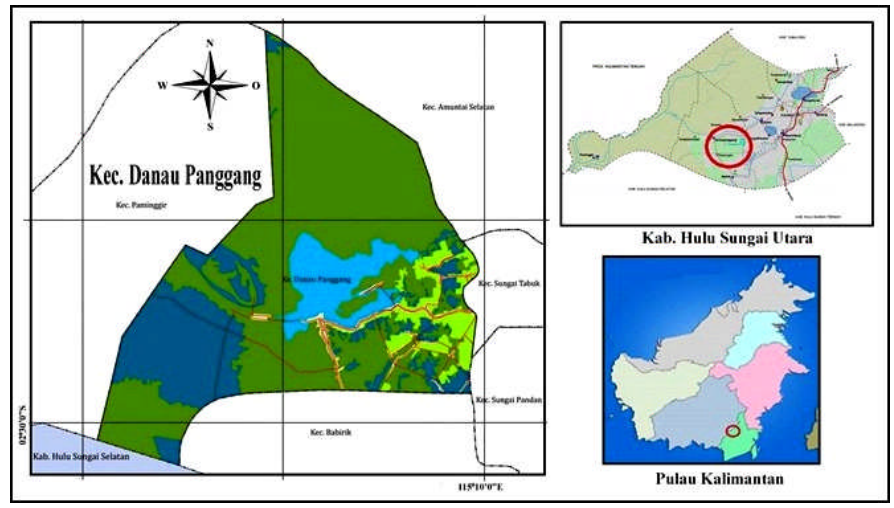

Gambar 1. Lokasi pengambilan sampel.

Figure 1. Sampling site location. 
Tabel 1. Deskripsi jenis alat penangkapan yang dioperasikan nelayan

Table 1. Description of fishing gears were operated by fishermen

\begin{tabular}{ccc}
\hline \hline No & Alat Penangkapan \\
Ikan//
\end{tabular}

Fishing Gear

\section{Description}

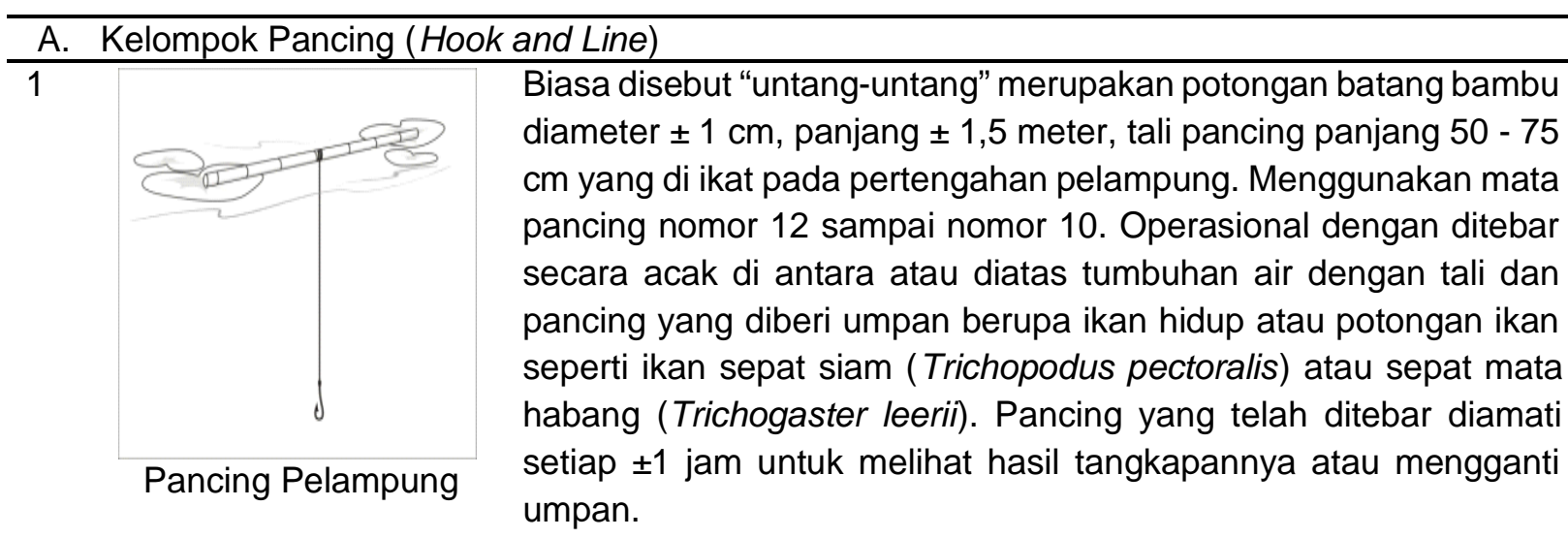

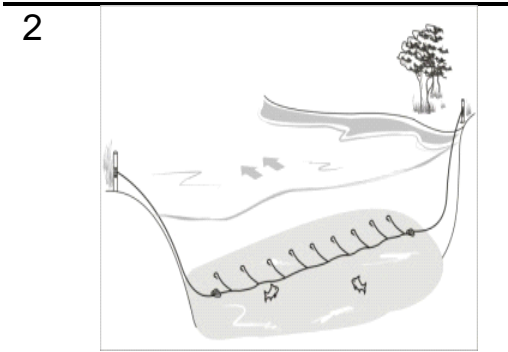

Rawai Baung

Merupakan pancing dasar yang terdiri dari: tali ris utama ( main line) dari bahan poli etilen (PE) diameter 2 - $3 \mathrm{~mm}$, tali cabang (branch line), polyamide (PA) mono diameter 0,5 -0,9 mm, panjang tali 40 $60 \mathrm{~m}$. Satu unit pancing rawai $40-60$ mata pancing. Operasional dengan membentangkan memotong lebar sungai, dan ditambahkan pemberat berupa batu. Alat ini mengggunakan umpan berupa buah-buahan dan potongan daging ikan ataupun serangga.

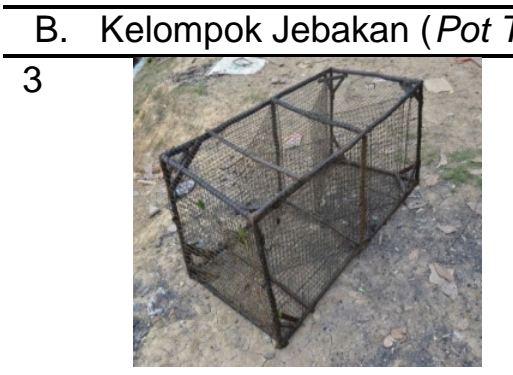

Lukah Baung

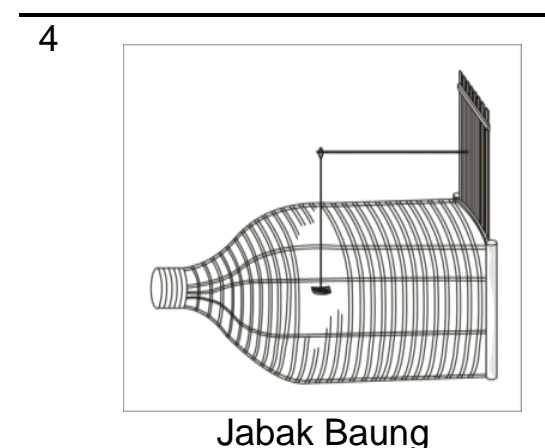

Merupakan alat penangkapan ikan pasif terbuat dari jalinan potongan bambu yang dianyam membentuk silinder yang mengecil pada salah satu bagian ujung nya, mesh size alat $1-2 \mathrm{~cm}$. Bagian mulut dipasang pintu jebakan yang terbuat dari bilah bambu dan dilengkapi dengan karet atau semacam busur dan berhubungan dengan tempat umpan. Pintu secara otomatis akan tertutup bila umpan dalam jebakan bergerak di makan atau disentuh ikan atau udang. 


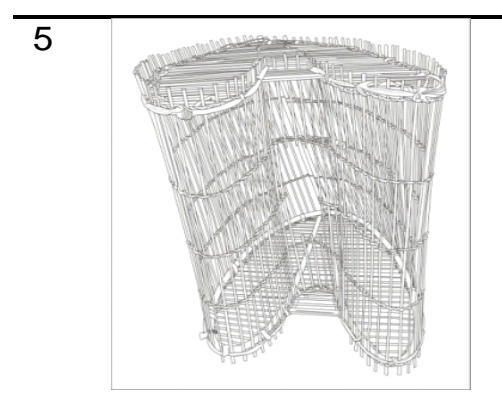

Tampirai

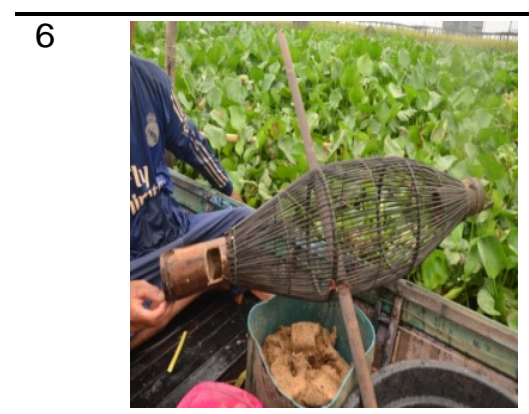

Tamba seluang
Alat berbentuk oval yang dibuat dari rotan atau bilah bambu, dinding bilah rotan, bilah bambu, jaring, kawat. Ukuran diameter $40-60 \mathrm{~cm}$ ringgi $60-80 \mathrm{~cm}$, mesh size $1-2 \mathrm{~cm}$. Pemasangan dilakukan dengan bagian mulut tampirai searah arus air, menggunakan umpan yang diletakan dalam alat, sebagian permukaan alat dipasang timbul dari permukaan air agar ikan yang tertangkap dapat mengambil udara sehingga ikan tidak cepat mati.

Alat penangkapan ikan berbentuk silinder ukuran diamater \pm 25 $\mathrm{cm}$ tinggi $30 \mathrm{~cm}$, bentuk silinder yang mengecil pada kedua ujungnya diameter tengah \pm 30 , diamater ujung $\pm 10 \mathrm{~cm}$ panjang $\pm 60 \mathrm{~cm}$, setiap alat diikat pada stik kayu atau bambu. Bagian samping botol dipasang potongan bambu diameter \pm 10 $\mathrm{cm}$, panjang $\pm 20 \mathrm{~cm}$ sebagai tempat umpan dan injab. Dipasang pinggiran sungai utama, anak sungai dan rawa, arus air tenang sampai sedang. Satu orang nelayan dapat memasang sejumlah $40-60$ buah alat.

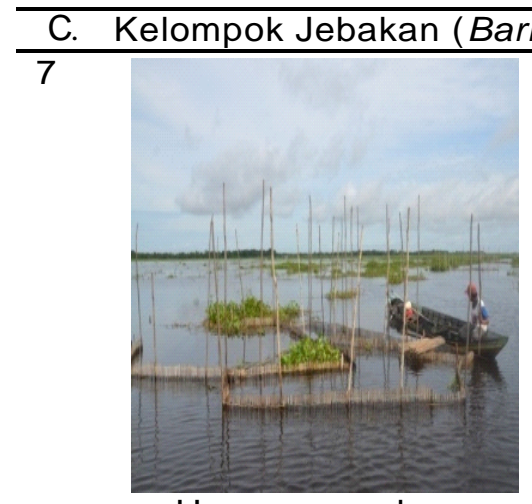

Hampang padang

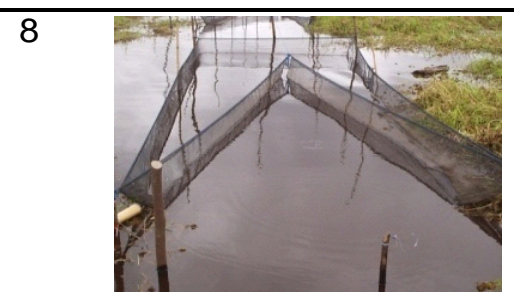

Selambau Kasa

\begin{abstract}
Alat penangkapan ikan yang terdiri dari hampang (barrier) meshsize 1,0 -2,0 cm sebagai barrier untuk menghadang dan mengarahkan ikan masuk dalam rumah ikan. Panjang hampang bagian kiri -kanan rumah ikan $30-50$ meter. Satu unit alat dibuat beberapa buah rumah ikan empat persegi panjang yang saling berhubungan masing-masing dengan injab bertujuan agar ikan yang masuk tidak mudah keluar.Alat dipasang menetap, ikan yang tertangkap dan masuk dalam rumah petak terakhir yang bisa diangkat kemudian dipasang kembali.
\end{abstract}

Alat penangkapan ikan bentuk kotak empat persegi panjang ukuranpanjang 8-10 meter lebar 4-6 meterdibuat dari bahan waring. Bagian depan dibuat injabberbentuk huruf $V$ dari bahan waring, sehingga ikan yang masuk tidak dapat keluar. Alat dipasang menetap yang diikatkan pada patok kayu untuk sepanjang tahun terutama musim ikan beruaya bermigrasi.

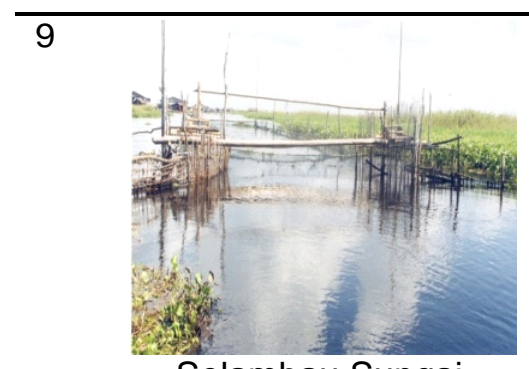

Alat penangkapan ikan bentuk empat persegi panjang yang terdiri dari rumah ikan (kantong hasil) dan hampang airuntuk menghadang dan mengarahkan ikan masuk dalam rumah ikan. Hampang dipasang kiri -kanan memotong badan sungai dan menyatu dengan mulut salambau, mulut salambau dipasang posisi menghadang arus air, mulai dasar perairan sampai \pm 50 $\mathrm{cm}$ dari permukaan air.Rumah ikan bentuk empat persegi panjang, bahan jaring $P E$, ukuran panjang $30-40$ meter, lebar $10-12$ meter, tinggi $5-7,0$ meter. 


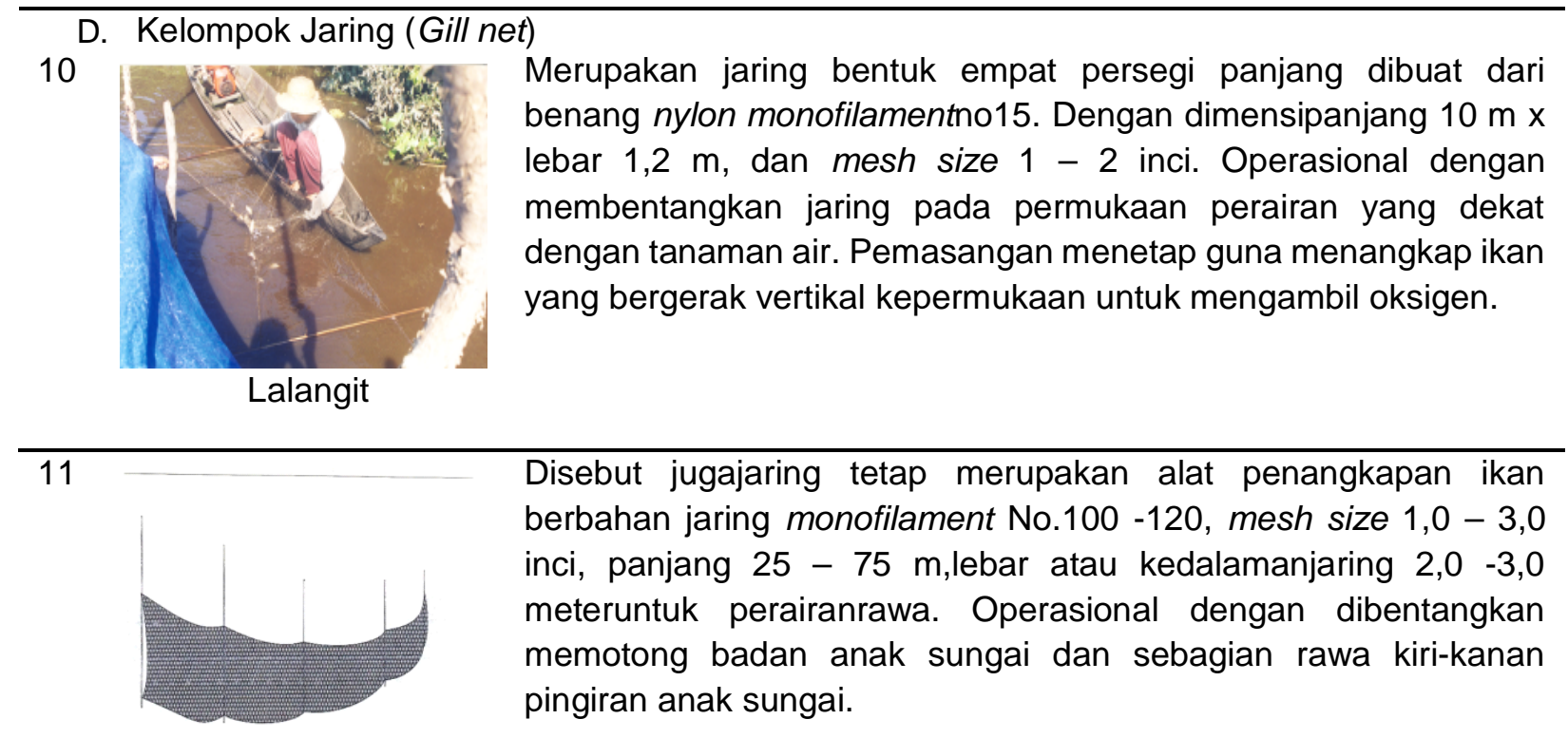

Rengge

Sumber: Rupawan et al. (2016)

\section{Analisis Data}

Hasil tangkapan total hasil tangkapan dihitung dari total hasil tangkapan nelayan enumerator dalam satu bulan dan dikelompokkan sesuai dengan jenis alat penangkapan ikan, serta ikan hasil tangkapannya. Nilai laju tangkap (1) setiap bulannya dihitung dari hubungan antara usaha penangkapan dibandingkan dengan hasil tangkapan (Nurhayati, 2013). Standarisasi nilai upaya penangkapan dilakukan dengan membandingkan tangkapan per upaya penangkapan masing-masing alat penangkapan ikan. Alat penangkapan ikan yang dijadikan standart adalah alat penangkapan ikan yang paling produktif dalam menangkap ikan dan memiliki nilai fishing power index (FPI) sama dengan satu (Badrudin et al., 2004). Untuk menyatakan hubungan antara tinggi muka air terhadap nilai laju tangkap dan hasil tangkapan hasil tangkapan dilakukan pengujian data memlalui uji $t$ test (Santoso, 2012).

Laju Tangkap $=\frac{C}{A}$

$\mathrm{FPI}=\frac{\text { Laju Tangkap }}{\text { Laju Tangkap Maksimum }}$

dimana:

$\mathrm{FPI}=$ Fishing Power Index
C = Produksi ikan per alat penangkapan ikan

A = Jumlah unit alat yang digunakan dalam usaha penangkapan

\section{HASIL DAN BAHASAN \\ Hasil}

\section{Hasil Tangkapan dan Laju Tangkap}

Hasil tangkapan dan penggunaan setiap alat penangkapan ikan ikan berbeda-beda pada setiap bulannya di Rawa Banjiran Danau Panggang, Kabupaten Hulu Sungai Utara (HSU) (Tabel 2). Alat penangkapan ikan yang digunakan sepanjang tahun adalah alat penangkapan ikan lukah baung dan tampirai dengan nilai hasil tangkapan 1.791,3 dan $4.134,7 \mathrm{~kg}$. Alat penangkapan ikan yang memiliki nilai hasil tangkapan terendah adalah jabak baung dengan total hasil tangkapan $146,2 \mathrm{~kg}$. Nilai total hasil tangkapan selambau sungai memiliki tingkat produktivitas tertinggi dengan total hasil tangkapan mencapai $9.143,3 \mathrm{~kg}$. Apabila dilihat dari kelompok alat penangkapan ikan, maka kelompok pancing (hook and line) memiliki ke samaan dalam waktu penggunaannya, sedangkan untuk kelompok alat jebakan (trap) penggunaanya cukup bervariatif dilihat dengan sebaran waktu penggunaan masing-masing alat penangkapan ikan yang berbeda. 
Tabel 2. Total hasil tangkapan pada setiap alat penangkapan ikan di Rawa Banjiran Danau Panggang Table 2. Total Catch by each fishing gear in Danau Panggang floods plain

\begin{tabular}{|c|c|c|c|c|c|c|c|c|c|c|c|c|}
\hline \multirow{2}{*}{ No } & \multirow{2}{*}{$\begin{array}{c}\text { Alat } \\
\text { Penangkapan } \\
\text { Ikan / Fishing } \\
\text { Gears } \\
\end{array}$} & \multicolumn{10}{|c|}{ Hasil Tangkapan/Production (kg) } & \multirow{2}{*}{ Total } \\
\hline & & Mar & Apr & May & Jun & Jul & Aug & Sept & Oct & Nov & Dec & \\
\hline \multicolumn{13}{|c|}{ Kelompok Pancing (Hook and line) } \\
\hline 1 & $\begin{array}{l}\text { Pancing } \\
\text { Pelampung }\end{array}$ & 99,9 & 184,9 & 125,8 & 300,9 & 290,3 & 223,2 & 49,0 & 55,5 & & & 1329,5 \\
\hline 2 & Rawai Baung & 38,6 & 62 & 50,6 & 269,3 & 153,9 & 277,3 & 111,6 & 85,1 & & & 1048,4 \\
\hline \multicolumn{13}{|c|}{ Kelompok Jebakan (PotTrap) } \\
\hline 3 & Lukah Baung & 45,6 & 33,4 & 49 & 78,4 & 45,5 & 591,4 & 534,9 & 282 & 116,8 & 14,1 & 1791,1 \\
\hline 4 & Jabak Baung & 21,5 & 23 & 19,3 & & & & & & 55 & 27,4 & 146,2 \\
\hline 5 & Tampirai & 164,9 & 243,8 & 126,2 & 819,5 & 723,3 & 468,4 & 231,5 & 797,3 & 486,7 & 73,1 & 4134,7 \\
\hline 6 & Kabam & 52 & 163 & 61 & 46,2 & 94 & & & & & & 416,2 \\
\hline \multicolumn{13}{|c|}{ Kelompok Jebakan (Barrier Trap) } \\
\hline 7 & $\begin{array}{l}\text { Hampang } \\
\text { Padang }\end{array}$ & 644,6 & 406,4 & 44,5 & 515,7 & 568 & & & 780,3 & & & 2959,5 \\
\hline 8 & $\begin{array}{l}\text { Selambau Kasa } \\
\text { Selambau }\end{array}$ & 288,7 & 526 & & 440 & 456 & 225 & 295 & 202 & & & 2432,7 \\
\hline 9 & Sungai & & & 136,9 & 1102,6 & 1599,3 & 2375,9 & 3928,6 & & & & 9143,3 \\
\hline \multicolumn{13}{|c|}{ Kelompok Jaring (Gill net) } \\
\hline 10 & Lalangit & & & 79,5 & 16,5 & 61,2 & & & 50,2 & 98,1 & 42,9 & 348,4 \\
\hline 11 & Rengge & & & & 26,3 & 143,3 & 155,3 & & & & & 324,9 \\
\hline
\end{tabular}

Fluktuasi hasil tangkapan berbagai alat penangkapan ikan di perairan rawa banjiran ditampilkan dalam Tabel 3. Pada kelompok alat pancing, alat penangkapan ikan pancing pelampung memiliki nilai laju tangkap lebih besar dibandingkan dengan rawai baung. Hal ini menunjukan pancing pelampung lebih besar probabilitasnya dalam menangkap ikan target seperti ikan haruan (Channa striata). Pada kelompok alat jebakan, laju tangkap dari selambau sungai sangat mendominasi dibandingkan alat penangkapan ikan lain, meski hanya di gunakan dalam waktu yang relatif singkat. Dalam kelompok alat penangkapan ikan jaring nilai laju tangkap dari rengge lebih tinggi dibandingkan dengan alat penangkapan ikan lalangit.

Tabel 3. Nilai laju tangkap pada setiap alat penangkapan ikan di Rawa Banjiran Danau Panggang Table 3. Fishing rate by each fishing gear in Danau Panggang floods plain

\begin{tabular}{|c|c|c|c|c|c|c|c|c|c|c|c|}
\hline \multirow{2}{*}{ No } & \multirow{2}{*}{$\begin{array}{l}\text { Alat penangkapan } \\
\text { ikan / Fishing Gears }\end{array}$} & \multicolumn{10}{|c|}{ Laju Tangkap/Fishing Rate (kg/catch) } \\
\hline & & Mar & Apr & May & Jun & Jul & Aug & Sept & Oct & Nov & Dec \\
\hline \multicolumn{12}{|c|}{ Kelompok Pancing (Hook and line) } \\
\hline 1 & Pancing Pelampung & 0,057 & 0,049 & 0,040 & 0,041 & 0,056 & 0,051 & 0,020 & 0,020 & & \\
\hline 2 & Rawai Baung & 0,030 & 0,025 & 0,022 & 0,039 & 0,034 & 0,037 & 0,023 & 0,019 & & \\
\hline \multicolumn{12}{|c|}{ Kelompok Jebakan (Trap) } \\
\hline 3 & Lukah Baung & 0,064 & 0,079 & 0,072 & 0,079 & 0,228 & 0,282 & 0,257 & 0,114 & 0,100 & 0,078 \\
\hline 4 & Jabak Baung & 0,072 & 0,046 & 0,043 & & & & & & 0,044 & 0,046 \\
\hline 5 & Tampirai & 0,507 & 0,325 & 0,361 & 0,628 & 0,984 & 0,646 & 0,403 & 0,514 & 0,444 & 0,200 \\
\hline 6 & Kabam & 3,250 & 2,717 & 1,605 & 2,100 & 1,621 & & & & & \\
\hline \multicolumn{12}{|c|}{ Kelompok Jebakan (Barrier Trap) } \\
\hline 7 & Hampang Padang & 4,775 & 4,516 & 1,236 & 2,122 & 2,427 & & & 5,100 & & \\
\hline 8 & Selambau Kasa & 9,623 & 18,786 & & 7,333 & 7,600 & 3,629 & 4,917 & 3,483 & & \\
\hline 9 & Selambau Sungai & & & 7,205 & 44,104 & 59,233 & 84,854 & 135,469 & & & \\
\hline \multicolumn{12}{|c|}{ Kelompok Jaring (Gill net) } \\
\hline 10 & Lalangit & & & 0,318 & 0,110 & 0,612 & & & 0,143 & 0,131 & 0,132 \\
\hline 11 & Rengge & & & & 0,877 & 0,796 & 0,398 & & & & \\
\hline
\end{tabular}

\section{Fluktuasi Penggunaan Alat Penangkapan Ikan Terhadap Tinggi Muka Air}

Fluktuasi tinggi muka air pada setiap bulan diikuti dengan dinamika perubahan penggunaan alat penangkapan ikan yang digunakan nelayan Kecamatan Danau Panggang (Gambar 2). Waktu puncak tertinggi permukaan air tercatat terjadi pada April (3,67 meter) hingga Juni (3,71 meter), dan mulai menurun hingga titik terendah pada Oktober $(3,10$ 
meter). Alat penangkapan ikan tampirai dan lukah baung dari kelompok alat jebakan merupakan alat penangkapan ikan yang digunakan sepanjang tahun, akan tetapi tidak memiliki persentase penggunaan tertinggi pada saat air puncak maupun level air terendah. Alat pancing pelampung konsiten tertinggi digunakan selama level air tinggi, dan mulai turun penggunaannya seiring dengan menurunnya level permukaan air $(23,79-46,30 \%)$. Alat penangkapan ikan lain yang dominan digunakan adalah rawai baung dari kelompok pancing, dimana alat ini menunjukan trend yang berbeda yaitu penggunaan di saat level air tinggi berkisar (30,87\%-40,16\%), dan cenderung meningkat pada saat level air menurun $(37,18$ $50,56 \%)$. Alat penangkapan ikan yang banyak digunakan pada saat level air naik yaitu November dan Desember adalah jabak baung, tampirai dan lalangit.

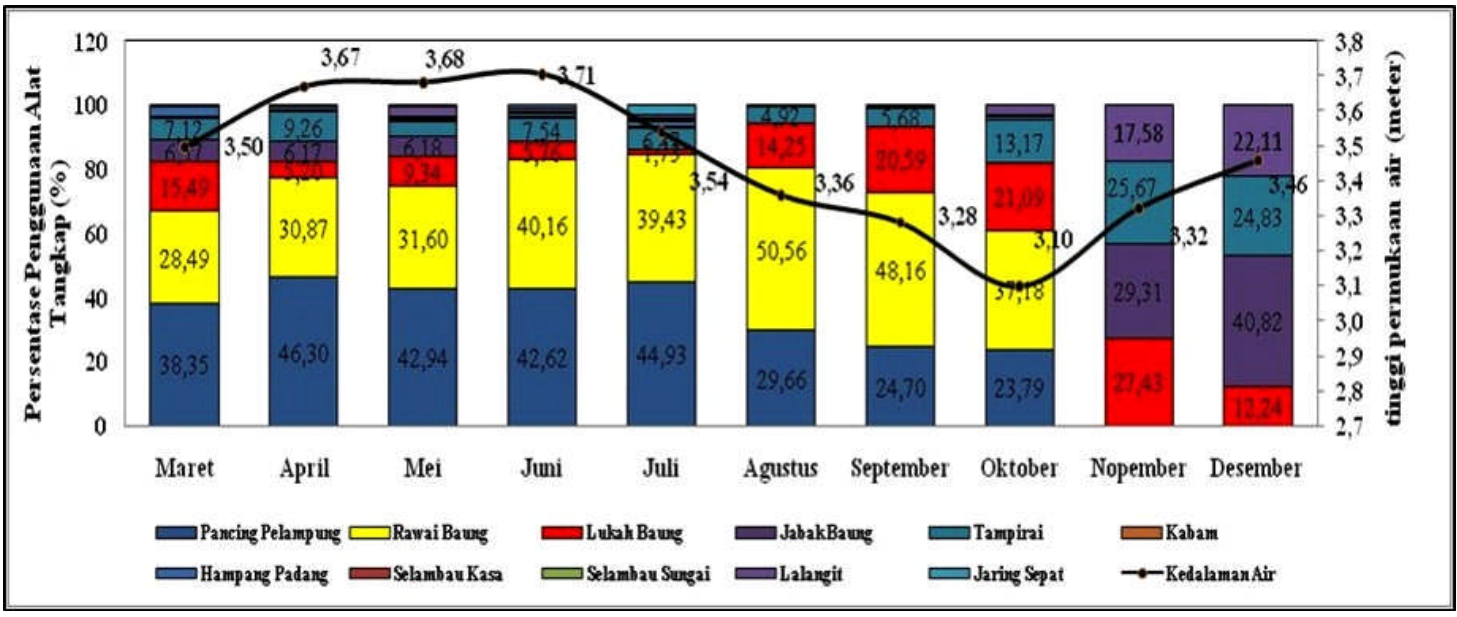

Gambar 2. Fluktuasi tinggi permukaan air terhadap persentase penggunaan alat penangkapan ikan.

Figure 2. Water level fluctuation to fishing gears utilities percentage.

\section{Komposisi Hasil Tangkapan}

Berbagai jenis ikan diperoleh selama penelitian menggunakan sebelas jenis alat penangkapan ikan. Tercatat diperoleh 31 spesies termasuk ikan dan udang yang tertangkap ditampilkan pada Tabel 4. Terlihat bahwa alat penangkapan ikan hampang padang, selambau kasa dan selambau sungai memiliki hasil tangkapan yang paling beragam dibandingkan dengan alat lainnya yang digunakan. Hal ini menjadikan ketiga alat tersebut bersifat lebih tidak selektif pada target spesies tertentu. Ikan baung (Hemibagrus nemurus) dan sepat siam (Trichopodus pectoralis) menjadi ikan yang paling banyak tertangkap. Ikan baung tertangkap menggunakan alat penangkapan ikan pancing pelampung, rawai baung, lukah baung, jabak baung, hampang padang dan selambau sungai. Ikan sepat siap tertangkap menggunakan alat penangkapan ikan lukah baung, tampirai, kabam, selambau kasa, lalangit dan rengge. Sepanjang musim ikan nila (Oreochromis niloticus) banyak tertangkapan menggunakan tempirai, dan ikan baung tertangkap menggunakan lukah baung. Dari persentase total hasil tangkapan, ikan baung menjadi spesies target dan paling ekonomis dalam kegiatan penangkapan di wilayah rawa banjiran Danau Panggang.

Komposisi hasil tangkapan hampang padang, selambau kasa, dan selambau sungai cukup bervariasi, karena sifatnya yang menetap dan menghadang aliran air. Tercatat 10 hingga 16 spesies tertangkap oleh alat penangkapan ikan hampang padang. Alat penangkapan ikan hampang padang memiliki produktifitas tertinggi pada Oktober dengan persentase tertinggi adalah ikan salap (Puntioplites falcifer). Alat penangkapan ikan selambau kasa optimal menangkap pada level air tertinggi dengan didominasi oleh ikan mangki (Rasbora trifasciata) dan ikan tembakang (Helostoma temminckii). Untuk alat penangkapan ikan selambau sungai memiliki puncak hasil tangkapan penangkapan pada September dengan didominasi oleh ikan patin (Pangasius djambal) dan ikan baung.

\section{Hubungan Laju Tangkap terhadap Tinggi Muka Air}

Nilai laju tangkap seluruh alat penangkapan ikan yang digunakan pada setiap bulannya mengalami fluktuasi. Penentuan alat penangkapan ikan yang digunakan sebagai standart dalam perhitungan Fishing Power Index (FPI) berbeda beda tergantung dari hasil tangkapan masing-masing alat pada setiap bulannya. Nilai hasil tangkapan hasil tangkapan diperoleh dari total dari hasil tangkapan nelayan enumerator sepanjang tahun penelitian. Fluktuasi nilai laju tangkap, hasil tangkapan hasil tangkapan dan fluktuasi tinggi muka air ditampilkan pada Gambar 3. 
Tabel 4. Komposisi dan persentase hasil tangkapan pada setiap alat penangkapan ikan

Table 4. Composition and percentage of catch by on each fishing gears

\begin{tabular}{|c|c|c|c|c|c|c|c|c|c|c|c|c|c|}
\hline \multirow[t]{2}{*}{ No } & \multirow{2}{*}{$\begin{array}{l}\text { Nama Lokal/ } \\
\text { Local Name }\end{array}$} & \multirow{2}{*}{$\begin{array}{l}\text { Nama IImiah/ } \\
\text { Scientific Name }\end{array}$} & \multicolumn{11}{|c|}{$\begin{array}{c}\text { Alat Penangkapan Ikan (\%) } \\
\text { Fishing gears (\%) }\end{array}$} \\
\hline & & & A & B & C & D & $E$ & $\mathrm{~F}$ & G & $\mathbf{H}$ & $\mathrm{I}$ & $\mathbf{J}$ & $\mathrm{K}$ \\
\hline 1 & Baung & Hemibagrus nemurus & 7,1 & 97,6 & 87,6 & 90,2 & & & 2,3 & & 14,7 & & \\
\hline 2 & Papuyu & Anabas testudineus & & & & & & & & & & 69,9 & \\
\hline 3 & Bintuhukan & Thynnichthys thynnoides & & & & & & & 0,2 & & & & \\
\hline 4 & Birahmata & Amblyrhynchichthys truncates & & & & 9,9 & & & & & & & \\
\hline 5 & Haruan & Chana striata & 92,9 & 1,6 & 0,8 & & & & 0,5 & & & & \\
\hline 6 & Jelawat & Leptobarbus hoeveni & & & & & & & & 0,4 & & & \\
\hline 7 & Kalabau & Osteochilus kelabau & & & & & & & 6,0 & 0,8 & 12,3 & & \\
\hline 8 & Kerandang & Channa pleurophthalma & & & & & & & 0,7 & & 0,8 & & \\
\hline 9 & Lais & Phalacronotus micronemus & & & & & & & 8,2 & 3,3 & 11,8 & & \\
\hline 10 & Lais kaca & Kryptopterus minor & & & & & & & & & 3,5 & & \\
\hline 11 & Lais kuning & Kryptopterus schilbeides & & & & & & & 6,5 & 3,5 & 25 & & \\
\hline 12 & Lais tabirin & Belodontichthys dinema & & & & & & & & & 0,2 & & \\
\hline 13 & Lais Putih & Kryptopterus kryptopterus & & & & & & & & 0,2 & & & \\
\hline 14 & Lampam & Barbonymus schwanenfeldii & & & & & & & & & & & 1,5 \\
\hline 15 & Lawang & Pseudolais micronemus & & & & & & & & & 7,5 & & \\
\hline 16 & Manangin & Thynnichthys polylepis & & & & & & & & & & & 1,2 \\
\hline 17 & Mangki & Rasbora trifasciata & & & & & & & & 18,6 & & & \\
\hline 18 & Nila & Oreochromis niloticus & & & 3,4 & & 66,3 & & 14,7 & & & & \\
\hline 19 & Patin & Pangasius djambal & & & & & & & & & 20,9 & & \\
\hline 20 & Pentet & Clarias bratachus & & 0,8 & & & & & 20,5 & & 0,3 & & \\
\hline 21 & Patung & Pristolepis grootii & & & & & & & & 3,6 & & & \\
\hline 22 & Puyau & Osteochilus schlegelii & & & & & & & 15,3 & 11 & 0,5 & & \\
\hline 23 & Riu & Pangasius macronema & & & & & & & & & 0,6 & & \\
\hline 24 & Salap & Puntioplites falcifer & & & & & & & 24,3 & & & & \\
\hline 25 & Sanggang & Puntioplites bulu & & & & & & & 0,7 & & 1,1 & & \\
\hline 26 & Sanggi & Mystusatrifasciatus & & & & & & & & & 0,7 & & \\
\hline 27 & $\begin{array}{l}\text { Sepat mata } \\
\text { habang }\end{array}$ & Trichogaster lerii & & & & & & 12,5 & & 3,9 & & & 49,5 \\
\hline 28 & Sepat Siam & Trichopodus pectoralis & & & 8,2 & & 33,1 & 51,2 & & 39 & & 30,1 & 47,8 \\
\hline 29 & Tambakang & Helostoma temminckii & & & & & 0,7 & 36,3 & & 15,8 & & & \\
\hline 30 & Tapah & Wallago leeri & & & & & & & & & 0,5 & & \\
\hline 31 & Udang Satang & Macrobrachium rosenbergii & & & & & & & 0,2 & & & & \\
\hline
\end{tabular}

Keterangan: $\mathrm{A}=$ Pancing Pelampung, $\mathrm{B}=$ Rawai Baung, $\mathrm{C}=$ Lukah Baung, $\mathrm{D}=$ Jabak Baung, $\mathrm{E}=$ Tampirai, $\mathrm{F}=$ Kabam, $\mathrm{G}=$ Hampang Padang, $\mathrm{H}$ = Selambau Kasa, $\mathrm{I}=$ Selambau Sungai, $\mathrm{J}=$ Lalangit, $\mathrm{K}$ $=$ Rengge.

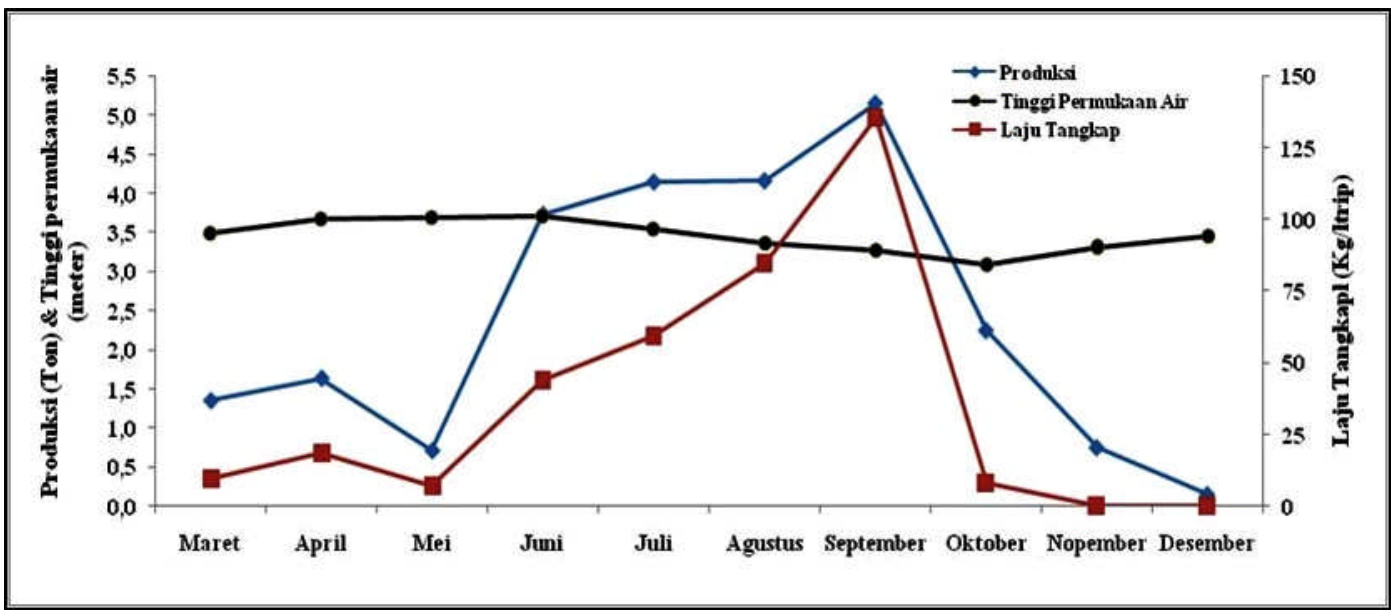

Gambar 3. Fluktuasi laju tangkap, hasil tangkapan dan tinggi muka air.

Figure 3. Fluctuation of fishing rate, catch and water level.

Nilai laju tangkap dan hasil tangkapan tangkap menunjukkan kenaikan yang signifikan pada Juni hingga September yaitu disaat level air mulai turun drastis. Hal ini menunjukkan aktivitas tangkap opti- mal pada saat air mulai surut, bukan disaat level air pada level air terendah. Bertolak belakang dengan kondisi level air yang tinggi dimana nilai laju tangkap dan hasil tangkapan tangkap menurun pada Maret 
hingga Mei. Hasil analisa hubungan laju tangkap dan total hasil tangkapan hasil tangkapan terhadap tinggi permukaan air melalui uji t-testmenunjukan nilai yang berbeda. Dalam tingkat kepercayaan 95\%, hasil analisis menunjukkan bahwa nilai laju tangkap terhadap tinggi permukaan air signifikan berkorelasi $(P<0,05)$, hal ini menunjukkan keterkaitan yang erat akan aktivitas tangkap terhadap fluktuasi level permukaan air. Keterkaitan hasil tangkapan hasil tangkap terhadap tinggi permukaan air tidak berkorelasi signifikan $(P>0,05)$, yang berarti hasil tangkapan hasil tangkapan tidak mutlak bekaitan dengan fluktuasi tinggi permukaan air.

\section{Bahasan}

Umumnya alat penangkapan ikan yang digunakan di perairan rawa banjiran merupakan alat penangkapan ikan pasif atau menetap. Alat penangkapan ikan pasif banyak digunakan karena wilayah yang relatif sempit, pembuatan, konstruksi atau pemasangan yang mudah, perairan yang dangkal dan juga berbagai jenis ikan yang tidak melakukan pergerakan terlalu jauh (Hubert et al., 2012). Bervariasinya penggunaan alat penangkapan ikan di perairan umum sangat ditentukan oleh pengaruh faktor hidrologi dan musim (Nurdawati et al., 2010). Alat penangkapan ikan seperti halnya lukah baung dan tampirai digunakan sepanjang tahun dikarenakan alat penangkapan ikan ini termasuk alat yang mudah dalam pemasangan, tidak terlalu terpengaruh terhadap kondisi perairan, dan juga mudah dalam pembuatannya. Alat penangkapan ikan pancing pada dasarnya dapat digunakan sepanjang tahun dengan selektifitas yang baik, yaitu dengan memvariasikan jenis umpan dan juga ukuran mata kail (Grixti et al., 2007). Pada kelompok perangkap operasionalnya adalah menetap dan bentuknya sangat beragam menyesuaikan dengan kondisi habitat dan hidrologinya. Alat penangkapan ikan perangkap tidak selektif terhadap spesies tertentu, hanya akan lebih ramah apabila ukuran meshsize nya cukup besar (McClanahan \& Mangi, 2004). Hal ini menunjukkan bahwa perubahan penggunaan alat penangkapan ikan hanya didasarkan kepentingan penggunaan alat penangkapan ikan yang mampu menangkap ikan dalam kuantitas lebih besar dan beragam pada musim tertentu.

Besarnya nilai laju tangkap sangat ditentukan oleh berapa armada atau unit alat yang digunakan dan juga ukuran ikan yang tertangkap. Nilai laju tangkap dan ukuran ikan yang menurun secara akumulatif mengindikasikan terjadinya over fishing (Kolding \& Zwieten, 2014). Alat penangkapan ikan selambau sungai dan selambau kasa tidak nampak menjadi alat yang dominan digunakan karena jumlahnya yang relatif tidak banyak. Harga hasil tangkapan alat penangkapan ikan yang tinggi menjadikan alat ini tidak banyak dimiliki oleh setiap nelayan. Nilai laju tangkap dan hasil tangkapan yang tinggi dari selambau kasa dan selambau sungai dikarenakan alat penangkapan ikan ini bersifat menghadang atau barieryang menutup sebagian aliran sungai dan juga migrasi ikan dari areal banjiran ke sungai utama (Hubert et al., 2012). Kemampuan alat penangkapan ikan untuk menangkap berbagai jenis dan ukuran ikan, ditambah dengan ukuran jaring yang sangat kecil sangat rentan untuk menekan kelangsungan hidup dan populasi ikan. Tekanan yang dialami akan berpengaruh terhadap ukuran ikan tertangkap, umur kematangan gonad, dan kelestarian sumberdaya ikan itu sendiri (Allan et al., 2005).

Perubahan alat penangkapan ikan dipandang dari kondisi hidrologi lebih erat dalam menjawab perubahan sifat distribusi ikan yang mengikut perubahan topografi dan level kedalaman perairan, sehingga diperlukan penyesuaian besarnya meshsize dan ukuran dari alat penangkapan ikan (Bhattacharjee \& Bhaskar, 2017). Dipandang dari sisi dinamika populasi perubahan penggunaan alat penangkapan ikan merupakan bentuk dari perubahan struktur komunitas dari berbagai ikan, dimana didalamnya terdapat adanya proses rekruitment, migrasi, dan juga stok biomassa dari ikan yang awalnya tersebar menjadi berkelompok dan sebaliknya (Kahl et al., 2008). Dari ke dua hal tersebut diperoleh gambaran bahwa terjadinya perubahan penggunaan alat penangkapan ikan adalah langkah adaptasi nelayan dalam perubahan pemanfaatan sumberdaya perikanannya guna pemenuhan kepentingan ekonominya terhadap perubahan struktur komunitas dan ekosistem dari sumberdaya ikan itu sendiri.

Ikan baung dan sepat siam menjadi ikan yang banyak tertangkap sepanjang tahun, dikarenakan perairan rawa banjiran, danau dan sebagian badan sungai merupakan habitat yang paling ideal khususnya sebagai habitat pemijahan (Chan et al., 2017). Menurut Adebiyi et al. (2011; 2013), siklus rehasil tangkapan ikan baung terjadi beberapa kali dalam setahun yaitu pada Januari, Juni dan November terutama pada saat level air pada puncak tertinggi. Sedangkan ikan sepat siam merupakan ikan asli perairan rawa banjiran, pola pergerakannya yang bergerombol dan juga bergerak secara vertikal untuk mengambil oksigen menjadikan berbagai alat penangkapan ikan mampu menangkap ikan ini. Tertangkapnya ikan nila sepanjang musim, dikarenakan sepesies ini memiliki kemampuan adaptasi yang baik dan mampu memijah sepanjang tahun. Dimana bulan-bulan utama dimana ditemukan 
ikan nila ditemukan matang gonad adalah Januari, April, Mei, Oktober, November, dan Desember (Khallaf et al., 2003).

Alat penangkapan ikan kelompok jebakan (barrier trap) memperoleh hasil yang paling beragam, dikarenakan sifatnya yang menghalau migrasi ikan dari arah daratan yang tertutup air disaat banjir kemudian surut dan kembali ke sungai utama (Muthmainnah \& Gaffar, 2017). Adanya migrasi ikan dari perairan sungai ke dalam wilayah rawa banjiran, dapat ditunjukkan dengan banyaknya tertangkap ikan putihan seperti ikan salap, ikan mangki dan ikan pating. Jenis ikan ini adalah ikan sungai yang masuk pada saat air sungai banjir dan menggenangi dataran banjiran untuk berbagai tujuan diantaranya adalah memijiah dan juga mencari makan (Silvano \& Jhon, 2008). Alat penangkapan ikan selambau sungai hanya dioperasikan dalam waktu yang pendek yaitu dari Mei hingga September, hal ini dikarenakan alat penangkapan ikan ini bersifat menetap, material pembangun yang besar, dan operasional yang membutuhkan usaha lebih dari dua orang. Proses pemanenan benar-benar harus memperhatikan kondisi perairan untuk efisiensi biaya operasional dan memperoleh hasil tangkapan yang optimal.

Korelasi signifikan yang menunjukkan turunnya level permukaan air berakibat terhadap kenaikan nilai laju tangkap terbukti secara uji-t. Hal ini meyakinkan bahwa pada perairan rawa banjiran aktivitas tangkap akan meningkat pada saat perairan mengalami penurunan. Hal ini disebabkan oleh besarnya biomassa ikan yang kembali ke badan sungai atau lokasi lebih rendah sehingga ikan akan berkumpul pada suatu area yang sempit dan proses penangkapan akan lebih mudah (Muthmainnah \& Gaffar, 2017). Berbeda dengan nilai hasil tangkapan yang menunjukan tidak adanya berkorelasi nyata terhadap tinggi permukaan air.Hal ini ditunjukan dengan menurunnya tinggi permukaan air tidak berakibat siginifikan terhadap nilai hasil tangkapan tangkap. Hal ini dapat diakibatkan beragamnya alat penangkapan ikan yang digunakan nelayan untuk menyesuaikan kondisi perairan. Menurut Weiperth et al. (2014), bahwa hasil tangkapan di perairan daratan lebih dipengaruhi oleh adanya variasi alat penangkapan ikan yang ditujukkan agar tangkapan lebih selektif terhadap sepesies target. Hasil tangkapan tangkap tidak terpengaruh secara signifikan terhadap fluktuasi tinggi muka air, dikarenakan beragamnya alat penangkapan ikan yang dimiliki nelayan dan penggunaan secara bergantian sesuai dengan kondisi lingkungan yang diinginkan.

\section{KESIMPULAN}

Kegiatan penangkapan dan jenis alat penangkapan ikan yang digunakan di wilayah perairan rawa banjiran di Kabupaten Hulu Sungai Utara telah mengalami adaptasi yang baik, sehingga dapat melakukan hasil tangkapan pada setiap musim secara stabil. Setiap alat penangkapan ikan memiliki ke khususan dalam mendapatkan target ikan tangkapan serta dimodifikasi dengan menyesuaikan tipologi setiap area penangkapan. Keberadaan alat penangkapan ikan barrier trap sangat produktif dalam menghasilkan tangkapan ikan, akan tetapi tetap diperlukan monitoring sehingga tetap dapat menjaga kelestarian sumberdaya ikan. Fluktuasi tinggi permukaan air tidaklah berpengaruh terhadap hasil tangkapan ikan, dikarenakan bervariasinya jenis alat penangkapan ikan sehingga nilai hasil tangkapan stabil sepanjang musim.

\section{PERSANTUNAN}

Karya ilmiah ini merupakan bagian dari hasil penelitian berjudul "Penggunaan Alat penangkapan ikan Ramah Lingkungan Daerah Aliran Sungai Barito, Kalimantan Tengah dan Kalimantan Selatan", pada T.A 2016 di Balai Riset Perikanan Perairan Umum, Palembang. Ucapan terimakasih penulis sampaikan kepada Bapak Drs. Budi Iskandar Prisantoso (Alm) selaku Kepala BRPPU, Bapak Rupawan, S.E selaku Ketua Tim Penelitian dan juga Pembimbing dalam penulisan makalah ini, serta Bapak Muhtarul Abidin dan Bapak Akhlis Bintoro, A.Md selaku teknisi yang sangat membantu sehingga penelitian ini dapat diselesaikan.

\section{DAFTAR PUSTAKA}

Adebiyi, F.A., Siraj, S.S., Hamrmin, S.A., \& Annie, C. (2011). Ovarian development of a river catfish Hemibagrus nemurus (Valenciennes, 1840) in captivity. Journal Exploration Zoology, 315, 536-543.

Adebiyi, F.A., Hamrmin, S.A., Siraj, S.S., \& Annie, C. (2013). Plasma sex steroid hormonal proûle and gonad histology during the annual reproductive cycle of river catûsh Hemibagrus nemurus (Valenciennes, 1840) in captivity. Fish Physiology and Biochemistry, 39, 547-557.

Allan, J.D., Abell, R., Hogan, Z., Revenga,. C., Taylor, B.D., Welcomme, R.L., \& Winemiller, K. (2005). Overfishing of Inland Waters. BioScience. University of California Press, 55(12), 1041-1051. 
Badan Pusat Statistik Kabupaten Hulu Sungai Utara. (2014). Hasil tangkapan dan nilai hasil tangkapan ikan darat dirinci tiap Kecamatan Tahun 2014. https://hulusungaiutarakab.bps.go.id/subject/56/ perikanan.html.

Badrudin, Sumiono, B., \& Nurhakim, S. (2004). Analisa data catch \& effort untuk pendugaan MSY (p. 1-14). IndonesiaMarine and Climate Support (IMACS) Project.

Béné, C., \& Friend, M.R. (2009). Water, poverty and inland fisheries: Lessons from Africa and Asia. Water International, 34(1), 47-61.

Bhattacharjee, M.,\& Bhaskar, M. (2017). A survey on fishing gears used for fishing in sone beel, The Largest Wetland in Assam, Northeast India. IJFAS, 5(4), 268-271.

Chan, B., Ngor, P.B., So, N., \& Sovan, L. (2017). Spatial and temporal changes in fish yields and fish communities in the largest tropical floodplain lake in Asia. International Journal of Limnology, 53, 485-493.

Dinas Perikanan HSU. (2015). RPIJM Kawasan Minapolitan Kab. Hulu Sungai Utara. Amuntai.

Froese, R., \& Pauly, D. (eds). (2018). FishBase. World Wide Web Electronic Publication. www.fishbase.org, version (06/2018).

Grixti, D., Simon, D.C., \& Jones, P.L. (2007). The effect of hook/bait size and angling technique on the hooking location and the catch of recreationally caught black bream acanthopagrus butcheri. Fisheries Research, 84, 338-344.

Hubert, W. A., Pope, K.L., \& Dettmers, J.M.(2012).Passive capture techniques. Fisheries techniques, $3^{\text {rd }}$ edition.American Fisheries Society, 223-265.

Kahl, U., Stephan, H. L. , Robert, J. R., \& Jurgen, B. (2008). The impact of water level ûuctuations on the year class strength of roach: implications for fish stock management. Limnologica, 38, 258268.

Khallaf, E.A., Mansour, G., \& Mohammad, A. (2003). The biology of oreochromis niloticus in a Polluted Canal. Ecotoxicology, 12, 405-416.
Kolding, J.,\& Zwieten, P.A.M. (2014). Sustainable fising of inland waters. Journal of Limnology, 73(1), 132-148.

Kottelat, M., Whitten, A.J., Kartikasari, S.N., \& Wirjoatmodjo, S. (1993). Freshwater fishes of western Indonesia and Sulawesi (Ikan air tawar Indonesia bagian Barat dan Sulawesi). Periplus Edition-Proyek EMDI. Jakarta.

McClanahan, T.R., \& Mangi, S.C. (2004). Gear-based management of tropical artisanan fishery based on species selectivity and capture size. Fisheries Management and Ecology. The Wildlife Conservation Society, 11, 51-60.

Muthmainnah, D., \& Gaffar, A.K. (2017). Fish and fisheries in flood plain swamp in middle part of Musi River. Indonesian Journal of Environmental Management and Sustainability, 1(1), 1-5.

Nurdawati, S., Rupawan, Makmur, S., \& Aroef, H.R. (2010). Aktivitas perikanan tangkap di Sungai Musi. Bunga Rampai Perikanan Perairan Sungai Musi Sumatera Selatan. Balai Riset Perikanan Perairan Umum. p. 209.

Nurhayati, A. (2013). Analisa potensi lestari perikanan tangkap di kawasan Pangandaran. Jurnal Akuatika, 4(2), 195-209.

Rupawan.,\& Aroef, H.R.(2016). Karakteristik penangkapan dan hasil tangkapan ikan di Kabupaten Barito Selatan, Kalimantan Tengah. J.Lit.Perik.Ind, 22(4), 215 - 224. http://dx.doi.org/ 10.15578/jppi.22.4.2016.215-224.

Rupawan., Emmy, D., Aroef, H.R., Tuah, N.M.W., Muhtarul, A., Akhlis, B., Mustakim., Khoirul, W., \& Tajidin., N. (2016). Penggunaan alat penangkapan ikan ramah lingkungan daerah aliran Sungai Barito, Kalimantan Tengah dan Kalimantan Selatan. Laporan Teknis Penelitian (Tidak dipublikasikan). Balai Penelitian Perikanan Perairan Umum. Palembang.

Santoso, S. (2012). Aplikasi SPSS pada statistikmultivariat (p. 47). Elex Media Computindo. Jakarta.

Silvano, R.A.M., \& John, V.J. (2008). Beyond ûshermen's tales: contributions of ûshers' local ecological knowledge to ûsh ecology and ûsheries management. Journal of Environmental Development and Sustainability,10(5), 657. 
Weiperth, A., Ferincz, Á., Keresztessy, K.,Kováts, N.,Szabó, I., Hufnagel, L.,Tátrai, I., Staszny, Á., \& Paulovits, G. (2014). Effect of water level fluctuations on fishery and anglers' catch data of economically utilised fish species of Lake Balaton Between 1901-2011. Applied Ecology And Environmental Research, 12(1), 221-249.
Zohary, T., \& Ilia, O. (2011). Ecological impacts of excessive water level fluctuations in stratified freshwater lakes. Inland Waters, 1(1), 47-59. 